\title{
MUNDO FICCIONAL Y MUNDO REAL EFECTIVO EN LA BALSA DE PIEDRA DE JOSÉ SARAMAGO
}

\author{
Mercedes Rodríguez Pequeño \\ Universidad de Valladolid
}

A través de una ficción literaria - la separación geográfica y conjunta de España y Portugal del resto de Europa-, José Saramago en A Jangada de Pedra (1986) intenta reconstruir una realidad histórica - la unidad ibérica - mediante una relación entre el mundo ficcional y el mundo real efectivo. Como queremos centrar nuestro interés en las características semánticas del referente literario representado en la obra narrativa, la metodología de la Teoría de los mundos posibles es la más adecuada a la hora de realizar el análisis e interpretación de la obra, pues además de tener en cuenta los aspectos semiótico-sintácticos que se dan en el texto, como el contenido y los tópicos textuales, extiende su campo al ámbito semántico extensional, que se ocupa de las relaciones semánticas entre el texto literario y el referente (organizado como estructura del conjunto referencial) o parte de la realidad extratextual que es incorporada al texto, y al ámbito pragmático que contiene al autor y al lector implicados en la obra y en la propiedad semántica de la ficcionalidad. Todo ello en una proyección renovadora del estudio de los textos narrativos.

En esta teoría, Tomás Albaladejo establece, dentro de la relación entre texto literario y mundo, «tres tipos de modelo de mundo a los que responden las estructuras de conjunto referencial de los textos verdaderos, ficcionales verosímiles, y ficcionales inverosímiles»"

1.- Tomás Albaladejo: Teoria de los mundos posibles y macroestructura narrativa. Análisis de las novelas cortas de Clarin, Alicante, Universidad de Alicante, 1985. 


\section{MERCEDES RODRÍGUEZ PEQUEÑO}

entendiendo por estructura de conjunto referencial el mundo representado por el texto. Tipos de modelos de mundo, de imágenes del referente previas al establecimiento de éste, que nos permiten conocer la singular ficción que caracteriza la narrativa de Saramago.

La organización de mundos de la fábula narrativa de La balsa de piedra ${ }^{2}$, establecida en torno a los cinco personajes y al narrador, quien presenta el sistema de mundos de los personajes y a la vez adopta la categoría de personaje de la narración, porque forma parte de la fábula como yo-testigo, gira alrededor de un contenido histórico apoyado en el discurso ficcional y de un mundo ficcional que sustenta el mundo verdadero de la historia. Estamos ante un texto ficcional narrativo que, con decidida voluntad del autor y al igual que otras de sus obras, se mueve entre la historia y la ficción, dependiendo sus referentes de los distintos modelos de mundo. Puesto que no podemos señalar, por la dimensión de este trabajo y por la extensión de la novela, todas las reglas que constituyen los mundos de los personajes y de la estructura de conjunto referencial, sirvan de ejemplo las que seleccionamos.

Hay en el modelo de mundo de La balsa de piedra elementos semánticos regidos por las reglas propias de un modelo de mundo del tipo III, ficcional no verosímil, construido según un modelo de estructuras de conjunto referencial que no podrían ser parte del mundo real efectivo: es ficcional inverosímil que cuando Joana Carda hace una raya en el suelo los perros mudos de Cerbère ladren y que la raya no desaparezca de ninguna manera. Es ficcional inverosímil que la piedra que Joaquim Sassa lanza al mar vuele durante largo tiempo y espacio. Y es ficcional inverosímil que José Anaiço sea acompañado por una nube de cerca de dos mil estorninos. También es ficcional inverosímil que Pedro Orce sea un sismógrafo ambulante y que cuando María Guavaira deshace un calcetín se encuentre con un interminable hilo azul. Y es ficcional inverosímil que, coincidiendo con estos hechos, se quiebren los Pirineos y la Península Ibérica se separe de Europa navegando por el Océano, expresado el elemento semántico correspondiente a este acontecimiento con unas reglas que no coinciden con las de la realidad efectiva, según entresacamos de la expresión propia del mundo del narrador y con el subrayado nuestro: «No podía nada la fuerza humana contra una cordillera que se abría como una granada, sin dolor aparente, y. sólo, quiénes somos nosotros para saberlo, por haber madurado y llegado su tiempon (p. 31).

Otros elementos semánticos están regidos por reglas propias del modelo de mundo de lo ficcional verosímil, tipo II, construido con reglas que aun siendo ficcionales son similares a las del mundo real efectivo. Por ejemplo, es ficcional verosímil que existan Joana Carda, Joaquim Sassa, José Anaiço, Pedro Orce, María Guavaira y el perro Constante. Es ficcional verosímil que Joana, José y Joaquim sean portugueses y Pedro y María son españoles. $\mathrm{Y}$ es ficcional verosímil que juntos emprendan un viaje y una nueva vida por España y Portugal.

Entre los elementos semánticos que constituyen los mundos de los personajes y que pertenecen al modelo de mundo de lo verdadero (tipo I), que coincide con la realidad efectiva, podemos mencionar, entre otras muchas proposiciones, que es verdadero que existen Portugal, España y Francia y las ciudades de Lisboa, Madrid, París, Granada, Valladolid, las islas Azores y el Océano Atlántico. Es verdadero que en Villalar tuvo lugar una batalla, y es verdadero que existen la CEE y la OTAN.

2.- José Saramago: La balsa de piedra, traducción del portugués de Basilio Losada, Barcelona, Seix Barral, 1988. 
La ley de máximos semánticos formulada por Tomás Albaladejo ${ }^{3}$, establece que las reglas de mayor nivel semántico (mayor alejamiento de la realidad efectiva) atraen a su modelo de mundo a las reglas de menor nivel semántico (mayor proximidad a la realidad efectiva) de manera que la combinación de elementos verdaderos y ficticios convierte a los verdaderos, de nivel semántico inferior, en ficcionales, de nivel semántico superior. Aplicando esta ley, el modelo de mundo al que queda adscrita esta novela es el de lo ficcional inverosimil. Sin embargo, la ficcionalidad de La balsa de piedra se consigue mediantc cl cuidado cquilibrio de los tres modclos de mundos: $\mathrm{el} \mathrm{de} \mathrm{lo} \mathrm{verdadero,} \mathrm{cl} \mathrm{dc}$ lo ficcional verosimil y el de lo ficcional no verosímil, y aquí radica también su acierto estético.

La relación entre el mundo real y el mundo ficcional, verosímil y no verosímil, se establece mediante una oportuna y equilibrada combinación de elementos. El modelo de mundo de lo verdadero, con elementos semánticos históricos y geográficos de la Península Ibérica, avala el proyecto de Saramago de la unión de España y Portugal en un destino común basado en una realidad — consanguinidad dice él-cultural, y la presencia de este modelo de mundo verdadero es necesaria para la construcción del modelo de mundo ficcional. Además, la relación entre la realidad efectiva y el referente del discurso ficcional nos introduce en la ficción de la obra, que se acerca y se aleja de la realidad intentando hacer compatibles los hechos verdaderos y los ficcionales. El modelo de mundo ficcional verosimil contribuye a dar sensación de verosimilitud a la obra reforzando la tesis anterior. En cuanto a la definitiva adscripción al modelo de mundo ficcional no verosimil, éste responde a la realidad expresada en el epígrafe que encabeza la novela y sintetiza su mensaje: "Todo futuro es fabuloso». El referente de La balsa de piedra participa de la realidad efectiva y de la ficción fantástica junto a la ficción realista, y en ellas se fundamenta su contenido temático.

El autor deja que muchos hechos permanezcan inexplicables e inverosímiles, ya que no son ni probables ni posibles. Y a pesar de ello el lector, que acepta las reglas que el autor ha seguido para la construcción del referente y elabora el mismo modelo de mundo establecido, reconoce formas de la realidad, pues la separación de la Península y su inexplicable navegar, generalmente acompañados estos hechos de elementos semánticos no verosímiles pero sí metafóricos, aparece íntimamente ligada a la estrecha vinculación de los países y su viaje común. Separación de carácter fíccional verosímil e incluso de carácter verdadero formando parte del submundo deseado del mundo real efectivo. La razón está en que los elementos semánticos del mundo ficcional no verosímil, centrados en la sorprendente navegación conjunta, actúan como término metafórico que nos remite poéticamente al término real metaforizado de la situación histórica deseada.

Como en La balsa de piedra aparece una proyección en el futuro, José Saramago necesita, además de los tipos I y II, propios de la narración realista, las reglas del modelo de mundo de tipo III, pues se trata no ya de convertir la historia en ficción, sino una ficción en historia futura, y, dado que es difícil deslindar lo que en el futuro será realidad o fantasía, Saramago juega con esta densidad equilibradora de elementos semánticos que quiere borrar la frontera entre la realidad y lo ficcional fantástico. La balsa de piedra, con la incorporación de elementos semánticos de la realidad efectiva y de elementos

3.- La ley de máximos semánticos y las restricciones a dicha ley han sido reformadas y ampliadas por el mismo Tomás Albaladejo en Semántica de la ficción literaria. La ficción realista, ejemplar mimeografiado, 1986, pp. 78-83. 


\section{MERCEDES RODRIGGUEZ PEQUEÑO}

semánticos de la ficción verosímil, pretende ser una ficción realizable. El componente semántico de lo ficcional no verosímil se vincula, o mejor, está copresente con la realidad efectiva, y, como carece de verosimilitud, aporta la dimensión utópica en la que José Saramago sitúa su creación de realidad. 